AperTO - Archivio Istituzionale Open Access dell'Università di Torino

\title{
Sesame seed labelling and health protection of allergic consumers
}

\section{This is the author's manuscript}

Original Citation:

Availability:

This version is available http://hdl.handle.net/2318/1705926

since 2019-07-09T16:09:26Z

Published version:

DOI:10.1108/BFJ-12-2017-0717

Terms of use:

Open Access

Anyone can freely access the full text of works made available as "Open Access". Works made available under a Creative Commons license can be used according to the terms and conditions of said license. Use of all other works requires consent of the right holder (author or publisher) if not exempted from copyright protection by the applicable law. 


\section{Sesame seed labeling and health protection of allergic consumers}

BIANCHI D.M. ${ }^{1}$, GALLINA S. ${ }^{1}$, IPPOLITO C. ${ }^{1}$, FRAGRASSI S. ${ }^{1}$, NUCERA D. ${ }^{2}$, DECASTELLI L. ${ }^{1}$ (2019)

1. IStituto ZOOPROFILATTICO SPERIMENTALE DEL PIEMONTE LIGURIA E VALLE D'AOSTA. TORINO (IT)

2. DIPARTIMENTO DI SCIENZE AGRARIE, FORESTALI ED ALIMENTARI (DISAFA), UNIVERSITA' DI TORINO, GRUGLIASCO, TORINO (IT)

\section{ABSTRACT}

Purpose. Sesame can cause food allergy and according to European legislation, its presence in food must be declared on the label. The purpose of this paper is to investigate the presence of sesame in food products carrying no mention of sesame on the ingredient label and in food products carrying the voluntary labelling statement "may contain traces of sesame".

Design/methodology/approach. Packaged bakery and non-bakery food items were collected at retail. Sample size was calculated according to estimated prevalence of 2 per cent and precision of 5 per cent: in total 32 samples of packaged bakery and nonbakery food were collected for each food category. The RIDASCREENÂ®FAST Sesame test (R-Biopharm AG, Darmstadt, Germany) was used for the analysis: its limit of detection was fixed in the laboratory at $0.5 \mathrm{ppm}$.

Findings. Of the 32 food samples that did not mention sesame seed on the ingredient label, one (3.1 per cent) breadsticks sample tested positive at a concentration (326ppm). Of the 32 food samples that carried the precautionary label statement "may contain traces of sesame", one (3.1 per cent) breadcrumbs sample tested positive (305ppm). Comparison between the allergen concentration and the published eliciting dose (ED5) for sesame proteins (1mg) was performed. The calculated exposure was more than 2 the ED05 reported in the literature.

Originality/value. To date, few studies investigating compliance with food-allergen labeling requirements are available. This survey provides data for preliminary risk assessment for sesame allergenic consumers.

PUBLISHED IN BRITISH FOOD JOURNAL, (EMERALD PUBLISHING LMT.) VOL 121 (4), PP 850-855,

DOI : $10.1108 / \mathrm{BFJ}-12-2017-0717$ 